\title{
PENGARUH AKUNTANSI KEPERILAKUAN TERHADAP SISTEM KEUANGAN DESA
}

\author{
Oleh : \\ Zainab $^{1)}$, Enza Resdiana ${ }^{2 * *}$ \\ ${ }^{1)}$ Program Studi Diploma III Akuntansi, Sekolah Tinggi Ilmu Ekonomi NU Trate Gresik, \\ ${ }^{2)}$ Fakultas Ilmu Sosial dan Politik, Universitas Wiraraja \\ E-mail : zainab@stienugresik.ac.id ${ }^{1)}$,enza@wiraraja.ac.id ${ }^{2)^{* *}}$
}

\begin{abstract}
This study aims to analyze the effect of behavioral accounting on the implementation of the village financial system. This type of research is exsplanatory research. The data used are primary data obtained from interviews and questionnaire result. The population in this study were all village financial system operators in Gresik are 356 villages. the sample of 190 with the yamane approach formula with using random sampling methode. The analysis tool used is multiple regression. The findings show that attitudes and training have a significant influence on the the village financial system, while motivation, perception and emotion have an influence on the village financial system.
\end{abstract}

Keywords: Behavioral Accounting, Village Financial System

\begin{abstract}
Abstrak
Penelitian ini bertujuan untuk menganalisis pengaruh akuntansi keperilakuan terhadap implementasi sistem keuangan desa. Jenis penelitian yang digunakan adalah penelitian eksplanatori. Data yang digunakan adalah data primer yang diperoleh dari hasil wawancara serta hasil isian kuisioner. Populasi dalam penelitian ini adalah seluruh operator sistem keuangan desa di wilayah Kabupaten Gresik sebanyak 356 desa. Pengambilan ukuran sampel dilakukan dengan menggunakan rumus pendekatan Yamane yaitu sebanyak 190 dan penentuan sampel menggunakan metode random sampling (sampel acak). Alat analisis yang digunakan menggunakan regresi berganda. Hasil temuan menunjukkan bahwa sikap dan pelatihan mempunyai pengaruh yang signifikan terhadap implementasi sistem keuangan desa, sedangkan motivasi, persepsi dan emosi memiliki pengaruh terhadap sistem keuangan desa.
\end{abstract}

Kata Kunci: Akuntansi Keperilakuan, Sistem Keuangan Desa

\section{PENDAHULUAN}

Dalam sistem pemerintahan desa saat ini, sistem keuangan memiliki pengaruh yang krusial terhadap keberlangsungan organisasi desa. Pelaksanaan APBDes memiliki peran penting dalam mensukseskan pembangunan daerah. Anggaran APBDes dapat mencerminkan kinerja dan kemampuan pemerintah desa dalam membiayai dan mengelola pembiayaan pemerintah serta pelaksanaan pembangunan desa. Pada kenyataannya banyak ditemukan keluhan masyarakat yang berkaitan dengan pengalokasian anggaran yang tidak sesuai dengan kebutuhan skala prioritas serta kurang mencerminkan aspek ekonomi, efisiensi dan efektifitas. (Mardiasmo, 2009).

Anggaran desa yang didistribusikan dari pusat akhir-akhir ini banyak yang tidak tepat sasaran dikarenakan kurangnya pemahaman aparat desa dalam mengelola anggaran. Sehingga 
anggaran yang selama ini diharapkan dapat memajukan desa disalahgunakan oleh oknum-oknum tertentu. Di sinilah letak akuntansi yang dapat menjembatani antara anggaran APBDes dengan pegawai yang mengelola sistem keuangan tersebut. Di sinilah fungsi akuntansi keperilakuan. Riset keperilakuan merupakan salah satu area penelitian yang penting dalam akuntansi. Fokus utamanya adalah bagaimana para pengguna informasi akuntansi mengambil keputusan dan informasi apa yang dibutuhkan. Akuntansi keperilakuan berkaitan dengan perilaku manusia dan hubungannya dengan desain, konstruksi dan penggunaan sistem informasi akuntansi secara efisien.

\section{TINJAUAN TEORITIS}

\section{Teori Atribusi}

Menurut Fritz Heider pencetus teori atribusi, teori atribusi merupakan teori yang menjelaskan tentang perilaku seseorang. Teori atribusi menjelaskan mengenai proses bagaimana kita menentukan penyebab dan motif tentang perilaku seseorang. Teori ini mengacu tentang bagaimana seseorang menjelaskan penyebab perilaku orang lain atau dirinya sendiri yang akan ditentukan apakah dari internal misalnya sifat, karakter, sikap, dll. ataupun eksternal misalnya tekanan situasi atau keadaan tertentu yang akan memberikan pengaruh terhadap perilaku individu (Luthans, 2005).

Pada dasarnya teori ini menyarankan bahwa jika seseorang mengamati perilaku seseorang individu, orang tersebut berusaha menentukan apakah perilaku itu disebabkan oleh faktor internal atau faktor eksternal yang tergantung pada tiga faktor, yaitu:

1. Kekhususan (ketersendirian), merujuk pada apakah seseorang individu memperlihatkan perilakuperilaku yang berlainan. Yang ingin diketahui adalah apakah perilaku ini luar biasa atau tidak. Jika luar biasa, maka kemungkinan besar pengamat memberikan atribusi eksternal kepada perilaku tersebut. Jika tidak, kelihatannya hal ini akan dinilai sebagai sifat internal.

2. Konsensus, yaitu jika semua orang yang menghadapi suatu situasi yang serupa bereaksi dengan cara yang sama

3. Konsistensi, dicari dari tindakan seorang apakah orang tersebut memberikan reaksi yang sama dari waktu ke waktu. Makin konsistensi perilaku, maka hasil pengamatan semakin cenderung untuk menghubungkan dengan sebabsebab internal.

\section{Sistem Keuangan Desa (Siskeudes)}


Sistem Keuangan Desa (Siskeudes) merupakan aplikasi yang dirancang oleh badan pengawas keuangan dan pembangunan (BPKP) dan Ditjen bina pemerintah desa kementrian dalam negri untuk membantu pemerintah desa dalam mewujudkan tata kelola keuangan desa yang berkualitas (BPKP,2016). Fitur-fitur yang ada dalam siskeudes dibuat sederhana agar mudah dalam penggunaannya.

\section{Akuntansi Keperilakuan}

Menurut Siegel \& Marconi (1989) akuntansi keperilakuan mempelajari hubungan antara perilaku manusia dengan sistem akuntansi. Sedangkan menurut (Lubis, 2017) bahwa akuntansi keperilakuan mempelajari aspek-aspek keperilakuan manusia yang berkaitan dengan proses pengambilan keputusan ekonomi. Ada beberapa faktor sosiologi, psikologi, psikologi sosial yang terdiri dari sikap, motivasi, persepsi, pembelajaran dan kepribadian (Siegel \& Marconi, 1989) dalam Sumirat (2006).

\section{Sikap}

Menurut Wibowo (2014) sikap merupakan pandangan terhadap suatu objek maupun orang atau kejadian dalam lingkungannya, melalui suatu pernyataan seseorang, yang menyenangkan maupun tidak menyenangkan. Sikap tercermin dalam perilaku yang ditunjukan oleh individu (Rosnidah et al., 2017). Sikap dapat berdampak pada penerapan sistem keuangan desa. Sikap yang baik lebih mudah berkonsentrasi sehingga akan tetap fokus dan tenang dalam mengoperasikan sistem keuangan. Penelitian Rombe et al. (2016) dan Akay et al. (2016) menyebutkan bahwa sikap berpengaruh signifikan terhadap implementasi siskeudes.

\section{Motivasi}

Motivasi merupakan dorongan untuk Dendi Purnama, Siti Nur Azizah Implementasi Sistem Keuangan Desa Berbasis Akuntansi Keperilakuan Page 163 bertindak terhadap rangkaian proses perilaku manusia dengan mempertimbangkan arah, intensitas, dan ketekunan pada pencapaian tujuan. Sedangkan elemen dalam motivasi meliputi unsur membangkitkan, mengarahkan, menjaga, menunjukkan intensitas, bersifat terus menerus dan adanya tujuan (Wibowo, 2014). Semakin tinggi motivasi aparatur desa, maka semakin cepat dalam memahami sistem keuangan desa karena dorongan untuk bisa menggunakan siskeudes semakin tinggi. Rombe et al. (2016) menyatakan bahwa motivasi berpengaruh signifikan terhadap implementasi siskeudes.

\section{Persepsi}

Persepsi adalah seperangkat proses yang dengannya kita mengenali, mengorganisasikan cerpaan-cerpaan 
indrawi yang kita terima dari stimuli lingkungan (Sternberg, 2008).

\section{Emosi}

Lubis (2017) menyatakan emosi dapat mempengaruhi perilaku bekerja. Emosi merupakan perasaan intens yang diarahkan pada seseorang atau sesuatu. Emosi seseorang dalam keadaan tenang dan rileks akan berdampak pada penggunaan sistem keuangan desa. Hal ini akan membuat seorang operator Siskeudes bekerja lebih nyaman dan mudah sehingga dalam pembuatan pelaporan akan lebih berkonsentrasi dan cepat selesai. Rombe et al. (2016) yang menyatakan bahwa emosi berpengaruh signifikan terhadap implementasi siskeudes, maka hipotesis yang diajukan adalah: H4 : emosi mempunyai pengaruh positif terhadap implementasi sistem keuangan desa.

\section{Pelatihan}

Mangkuprawira

menyebutkan bahwa dengan pelatihan karyawan akan semakin terampil dan mampu melaksanakan tanggung jawabnya dengan baik karena telah diajarkan pengetahuan dan keahlian tertentu serta sikap. Semakin sering operator siskeudes mengikuti pelatihan, maka akan semakin baik dan mampu dalam mengoperasikan sistem keuangan desa. Santa \& Damayanti (2018), dan Prabowo et al. (2014) menyatakan bahwa pelatihan berpengaruh signifikan terhadap penggunaan sistem informasi akuntansi, maka hipotesis yang diajukan adalah: H5 : Pelatihan mempunyai pengaruh positif terhadap implementasi sistem keuangan desa.

\section{HIPOTESIS}

\section{Pengaruh Sikap Terhadap Sistem Keuangan Desa}

Sikap merupakan pendapat dan penilaian yang ditujukan terhadap sistem keuangan desa (siskeudes) untuk menciptakan dan mempertahankan nilai melalui pengambilan keputusan dan pengelolaan sumber daya yang tepat.

H1 : Akuntansi keperilakuan berupa sikap berpengaruh positif terhadap sistem keuangan desa

\section{Pengaruh Motivasi Terhadap Sistem Keuangan Desa}

Motivasi merupakan aspek yang paling penting dalam akuntansi keperilakuan, dengan motivasi yang baik maka akuntansi dapat menjembatani sistem keuangan desa menjadi tepat sasaran terhadap tujuan dari manajemen.

$\mathrm{H} 2$ : Akuntansi keperilakuan berupa motivasi berpengaruh positif terhadap sistem keuangan desa

Pengaruh Persepsi Terhadap Sistem Keuangan Desa

Persepsi merupakan suatu proses yang dimulai dengan pengindraan, yaitu suatu stimulus yang diterima oleh individu melalui indra. Adapun faktor yang mempengaruhi individu antara lain : 
1. Faktor internal yang mempengaruhi persepsi, yaitu faktor yang terdapat dalam diri individu.

2. Faktor eksternal yang mempengaruhi persepsi, merupakan karakteristik dari lingkungan dan obyek-obyek yang terlibat didalamnya.

H3 : Akuntansi keperilakuan berupa persepsi berpengaruh positif terhadap sistem keuangan desa

\section{Pengaruh Emosi Terhadap Sistem Keuangan Desa}

Emosi merupakan kondisi perasaan manusia yang muncul karena perubahan fisik dan psikologis. Emosi manusia akan mempengaruhi bagaimana seseorang memiliki persepsi serta mempengaruhi pikiran dan tindakan yang dilakukan.

H4 : Akuntansi keperilakuan berupa emosi berpengaruh positif terhadap sistem keuangan desa

\section{Pengaruh Pelatihan Terhadap Sistem} Keuangan Desa

Pelatihan merupakan proses pendidikan jangka pendek yang menggunakan prosedur sistematis dan terorganisir. Dalam sistem keuangan desa pelatihan karyawannya menjadi sangat penting untuk dilakukan karena dengan memiliki pengalaman menjadikan karyawan tersebut lebih profesional dalam menjalankan tugasnya.
H5 : Akuntansi keperilakuan berupa pelatihan berpengaruh positif terhadap sistem keuangan desa.

\section{METODE PENELITIAN}

Jenis Penelitian dan Gambaran dari Populasi(Obyek)

Pendekatan dalam penelitian ini menggunakan pendekatan kuantitatif yang memerlukan perhitungan yang bersifat matematis. Model pengujian parameter, dimana data-data dari hasil daftar pertanyaan yang dilakukan pada target populasi yang ada. Sugiyono (2012:78), populasi adalah obyek yang akan diteliti yang mempunyai kualitas dan karakteristik tertentu yang ditetapkan oleh peneliti untuk dipelajari dan kemudian ditarik kesimpulannya. Populasi adalah sekelompok orang, kejadian atau segala sesuatu yang mempunyai karakteristik tertentu yang hendak diduga. Populasi dalam penelitian ini seluruh desa yang ada di kabupaten Gresik yang berjumlah 356 desa.

\section{Teknik Pengambilan Sampel}

Teknik pengambilan sampel yang di gunakan adalah rumus Slovin. Jumlah Populasi adalah perangkat desa yang menjadi operator siskeudes. Jumlah desa yang ada dikabupaten Gresik sebanyak 356 desa, sedangkan operator siskeudes masing-masing desa sebanyak satu orang sehingga populasi dalam penelitian ini 
sebanyak 356 orang. Dalam penelitian ini penulis menghitung ukuran sampel yang dilakukan presentase kelonggaran yang digunakan adalah $5 \%$ dan hasil perhitungan dapat dibulatkan untuk mencapai kesesuaian. Maka untuk mengetahui sampel penelitian. Dengan perhitungan sebagai berikut:

Jadi besar sampel dapat di hitung sebagai berikut:

$n=\frac{356}{\left(1+356(0,05)^{2}\right)}$

= 188,35; dibulatkan menjadi 190 Responden

Sampel yang dibutuhkan dalam penelitian ini adalah 190 responden. Adapun kriteria dalam pengambilan sampel ini adalah menjadi perangkat desa sekurang-kurangnya 6 bulan atau satu semester.

\section{Teknik Pengumpulan Data}

Penelitian ini menggunakan data primer. Data primer mengacu pada informasi yang dikumpulkan oleh seseorang, yang merupakan sumber asli atau pertama (Sekaran, 2006:65). Sumber data berdasarkan penyebaran kuesioner kepada responden langsung. Bobot penilaian atau angka hasil kuisioner dalam penelitian ini sesuai dengan skala Likert. Kuisioner tersebut dibagikan dan ditujukan kepada responden yaitu operator siskeudes di wilayah kabupaten Gresik.

\section{Variabel dan Definisi Operasional Variabel}

16 | Jurnal Public Corner Fisip Universitas Wiraraja

\section{Akuntansi keperilakuan}

Akuntansi bukanlah sesuatu yang statis, tetapi akan selalu berkembang sesuai dengan perkembangan lingkungan akuntansi serta kebutuhan organisasi akan informasi yang dibutuhkan oleh penggunanya (Arfan dan Ishak, 2005). Berdasarkan pemikiran tersebut manusia dan faktor sosial secara jelas didesain dalam aspek-aspek operasional utama dari seluruh sistem akuntansi.

\section{Sikap}

Perasaan ini timbul dari adanya evaluasi individual atas keyakinan terhadap hasil yang didapatkan dari perilaku tertentu. Sikap adalah suatu hal yang mempelajari mengenai seluruh tendensi tindakan baik yang menguntungkan maupun yang kurang menguntungkan, tujuan manusia, objek, gagasan, atau situasi. Objek pada sikap digunakan untuk memasukkan semua objek yang mengarah pada reaksi seseorang. Sikap berbeda dengan perilaku, sikap menghadirkan suatu kesiapsiagaan untuk tindakan yang mengarah pada perilaku (Lubis, 2010: 78-79).Sikap pada awalnya diartikan sebagai suatu syarat untuk munculnya suatu tindakan Fenomena sikap adalah mekanisme mental yang mengevaluasi, membentuk pandangan, mewarnai perasaan dan akan ikut menentukan kecenderungan perilaku kita terhadap manusia atau sesuatu yang 
kita hadapi, bahkan terhadap diri kita sendiri (Ningsing dan Achmad, 2014).

\section{Motivasi}

Motivasi adalah proses yang dimulai dengan definisi fisiologi atau psikologi yang menggerakkan perilaku atau dorongan yang ditunjukan untuk tujuan defensif (Lubis, 2010: 84). Motivasi memiliki pengaruh penting terhadap akuntansi keperilakuan, karena motivasi itu merupakan niat seseorang dalam melakukan sesuatu.

\section{Persepsi}

Persepsi merupakan serangkaian proses rumit yang melaluinya kita memperoleh dan mengintepretasikan informasi indrawi, interpretasi ini memungkinkan kita untuk memaknai lingkungan sekitar kita. Organisasi perseptual merupakan proses mengorganisasi komponen-komponen pemandangan menjadi objek-objek terpisah.

\section{Emosi}

Emosi diartikan sebagai impuls yang muncul akibat dari suatu rangsangan dari dalam maupun dari luar. Emosi bermacam macam, seperti emosi sedih, emosi marah, emosi bahagia, dan bentuk emosi lainnya. Emosi dalam bahasa awamnya seringkali dipakai untuk mendeskripsikan kemarahan saja, namun sebenarnya emosi memiliki arti yang lebih luar dan mewakili banyak macam perasaan.

Prez, 1999 merupakan seorang EQ organizasional consultant dan juga pengajar. Prezz mengungkapkan arti emosi adalah suatu reaksi tubuh dalam menghadapi sesuatu. Sifat dan intensitas emosi terkait erat dengan aktivitas kognitif sebagai hasil dari persepsi terhadap situasi.

\section{Pelatihan}

Pelatihan sebagai bagian dari pendidikan yang mengandung proses belajar untuk memperoleh dan meningkatkan keterampilan, waktu yang relatif singkat dan metode yang lebih mengutamakan praktek daripada teori.

\section{Sistem Keuangan Desa}

Sistem keuangan desa merupakan bagian dari program pemerintah untuk memberikan kenyamanan pada masyarakat sebagai bentuk transparansi laporan keuangan karena dengan sistem keuangan yang terintegrasi mampu mengurangi kecurangan yang ada.

\section{Teknik Analisis Data}

\section{Uji Validitas}

Menurut (Santoso, 2011:72), tujuan pengujian validitas adalah proses menguji butir-butir pertanyaan yang ada dalam sebuah angket, apakah isi dan butir pertanyaan tersebut sudah valid. Jika butirbutir sudah valid berarti butir tersebut sudah bisa untuk mengukur faktornya. 
Pengujian validitas menggunakan ketentuan jika signifikansi dari $r$ hitung atau $r$ hasil $>r$ tabel maka item variabel disimpulkan valid tetapi sebaliknya jika $r$ hitung atau rhasil <rtable maka item variabel disimpulkan tidak valid.

\section{Uji Reliabilitas}

Menurut (Sugiyono, 2012: 102) menyatakan bahwa reliabilitas adalah derajat ketepatan, ketelitian atau keakuratan yang ditunjukkan oleh instrumen pengukuran. Untuk mengukur reliabilitas dengan melihat cronbach alpha. Suatu konstruk atau variabel dapat dikatakan reliabel jika memberikan nilai cronbach alpha> 0,60 (Ghozali, 2011: 42).

\section{Analisis Regresi Berganda}

Metode analisis regresi berganda yaitu metode statistik untuk menguji hubungan antara beberapa variabel independen terhadap satu variabel dependen. Analisis ini bertujuan menguji hubungan antar variabel penelitian dan mengetahui besarnya pengaruh masingmasing variabel bebas terhadap variabel terikat.

\section{Uji Asumsi Klasik}

Uji normalitas bertujuan untuk menguji apakah dalam model regresi, variabel mengganggu atau residual memiliki distribusi normal. Untuk menguji apakah distribusi normal atau tidak, salah satunya adalah menggunakan metode analisis grafik dari normal $\mathrm{P}-\mathrm{P}$ Plot of
Regresion Standardizerd Residual, untuk mengetahuinya diasumsikan sebagai berikut: (1) Jika ada titik-titik data yang menyebar disekitar garis normal dan mengikuti arah diagonal, maka model regresi memenuhi asumsi normalitas; (2) Jika titik-titik data menyebar jauh dari garis diagonal dan atau tidak mengikuti arah garis diagonal. Maka model regresi tidak memenuhi asumsi normalitas.

Uji multikolinearitas untuk menguji apakah ada korelasi antar variabel bebas (independent). Menurut Santoso (2009:26), pedoman suatu model regresi yang bebas multikolinearitas adalah: (1) nilai VIF disekitar angka 10; (2) angka tolerance mendekati 1.

Uji heteroskedastisitas bertujuan untuk menguji apakah dalam model regresi terjadi kesamaan variabel dari residual satu pengamatan ke pengamatan lain. Jika variance dari residual satu pengamatan ke pengamatan lain tetap, maka disebut homoskedastisitas atau tidak terjadi heteroskedastisitas.

\section{Uji Kelayakan Model(Goodness of Fit)}

Uji kelayakan model pada dasarnya menunjukkan apakah semua variabel independen yang dimasukkan dalam model layak atau tidak. Ketentuan penerimaan atau penolakan uji kelayakan model adalah sebagai berikut: (1) Jika nilai signifikansi F $<0,05$ maka model dapat dikatakan 
layak; (2) Jika nilai signifikansi $\mathrm{F}>0,05$ maka model dapat dikatakan tidak layak.

Uji Koefisien Determinasi $\left(\mathbf{R}^{\mathbf{2}}\right)$

Nilai koefisien determinasi adalah antara 0 (nol) dan 1 (satu). Jika variabel $\mathrm{R}^{2}$ memiliki nilai 0 atau mendekati 0 , berarti kemampuan variabel independen dalam menjelaskan variabel dependen mengalami keterbatasan, tetapi jika variabel $\mathrm{R}^{2}$ memiliki nilai 1 atau mendekati 1 berarti variabel independen memberikan hampir semua informasi yang dibutuhkan untuk memprediksi variabel dependen. (Ghozali, 2011)

\section{Uji Hipotesis (Uji t)}

Pengujian dilakukan dengan menggunakan significance level 0,05 $(\alpha=5 \%)$. Penerimaan atau penolakan hipotesis dilakukan dengan kriteria sebagai berikut: (1) Jika nilai signifikansi t $>0,05$ maka hipotesis ditolak; (2) Jika nilai signifikansi $\mathrm{t} \leq 0,05$ maka hipotesis diterima.

\section{HASIL DAN PEMBAHASAN}

\section{Uji Validitas}

Uji validitas data dilakukan pada tiap indikator-indikator yang ada dengan 18 pernyataan baik itu variabel independen maupun dependen adalah valid dengan nilai $r$ tabel sebesar 0,138 .

\section{Uji Reliabilitas}

Uji reliabilitas mengarah pada konsistensi alat ukur, pengukuran menggunakan Cronbach Alpha. Suatu alat pengukuran dapat dikatakan reliabel apabila memiliki Cronbach Alpha $\geq 0,6$ (Ghozali, 2011 : 34). . Hasil dari uji reliabilitas, dapat diketahui bahwa semua variabel yaitu variabel akuntansi keperilakuan berupa sikap, motivasi, persepsi, emosi, pelatihan dan variabel sistem keuangan desa adalah reliabel karena memiliki nilai cronbach alpha yang lebih besar dari 0,60.

\section{Analisis Regresi Linier Berganda}

Dalam penelitian ini, analisis regresi berganda digunakan untuk memprediksi hubungan antara variabel akuntansi keperilakuan berupa sikap, motivasi, persepsi, emosi, pelatihan dan variabel sistem keuangan desa. Adapun hasil dari Analisis Regresi Linier Berganda tampak pada Tabel 1 
Tabel 1

Analisis Regresi Linier Berganda

\begin{tabular}{|c|c|c|c|c|c|}
\hline \multirow[t]{2}{*}{ Model } & \multicolumn{2}{|c|}{$\begin{array}{l}\text { Unstandardized } \\
\text { coefficients }\end{array}$} & \multirow{2}{*}{$\begin{array}{l}\text { Standardized } \\
\text { coefficients } \\
\text { Beta }\end{array}$} & \multirow[t]{2}{*}{$\mathbf{t}$} & \multirow[t]{2}{*}{ Sig. } \\
\hline & B & $\begin{array}{l}\text { Std. } \\
\text { Error }\end{array}$ & & & \\
\hline Constant & ,713 & ,728 & & ,771 & 000 \\
\hline Sikap & ,639 & ,166 & 1,802 & ,604 & ,000 \\
\hline Motivasi & ,566 &, 140 & ,493 & 671 & ,000 \\
\hline Persepsi & ,610 & , 108 & ,797 & ,780 & 000 \\
\hline Emosi & ,700 & ,067 & ,368 & ,699 & ,000 \\
\hline Pelatihan & ,888 & ,288 & ,554 & ,701 & ,000 \\
\hline SISKEUDES & ,609 & ,719 & ,488 & 699 & ,000 \\
\hline
\end{tabular}

Dependent Variable: Akuntabilitas Kinerja Perangkat Desa

dari tabel diatas dapat dijelaskan

bahwa variabel akuntansi keperilakuan berupa sikap, motivasi, persepsi, emosi dan pelatihan berpengaruh positif terhadap variabel SISKEUDES

\section{Uji Normalitas}

Hasil pengujian normalitas dengan menggunakan pendekatan grafik,dapat diketahui bahwa distribusi data telah mengikuti garis diagonal antara 0 (nol) dengan pertemuan sumbu Y (Expected Cum. Prob.) dengan sumbu X (Observed
Cum Prob.) Hal ini menunjukkan bahwa data dalam penelitian ini telah berdistribusi normal. Dengan demikian dapat disimpulkan bahwa model regresi telah memenuhi asumsi normalitas.

\section{Multikolinearitas}

Uji multikolinearitas digunakan untuk menguji model regresi ditemukan ada korelasi antar variabel bebas (independent). Hasil uji multikolinearitas, dapat diketahui bahwa besarnya nilai 
Variance Influence Factor (VIF) pada seluruh variabel akuntansi keperilakuan dan sistem keungan desa lebih kecil dari 10 dan nilai tolerance kurang dari 1, sesuai dengan ketentuan yang telah ditetapkan maka hal ini berarti model yang digunakan dalam penelitian tidak ditemukan adanya korelasi antar variable dan bisa disebut juga dengan bebas dari multikolinearitas, sehingga variabel tersebut dapat digunakan dalam penelitian.

\section{Uji Heteroskedastisitas}

Hasil dari uji heteroskedastisitas didapat titik-titik menyebar secara acak, tidak membentuk sebuah pola tertentu yang jelas, serta tersebar di atas maupun di bawah angka 0 pada sumbu Y, maka dapat disimpulkan bahwa tidak terjadi gangguan heteroskedastisitas pada model regresi. Hal ini menunjukkan bahwa hasil estimasi regresi linier berganda layak digunakan analisa lebih lanjut.

\section{Uji Kelayakan Model}

Uji kelayakan model pada dasarnya menunjukan apakah semua variabel akuntansi keperilakuan yang dimasukkan dalam model mempunyai pengaruh terhadap variabel sistem keuangan desa. Hasil dari Uji Kelayakan Model, tampak pada tabel 2

Tabel 2

\section{Hasil uji kelayakan model}

ANOVA $^{\text {b }}$

\begin{tabular}{|l|l|l|l|l|l|}
\hline \multicolumn{1}{|c|}{ Model } & \multicolumn{1}{|c|}{ Sum of Squares } & \multicolumn{1}{c|}{ df } & Mean Square & F & 19,251 \\
\hline Regression & 27,990 & 5 & 5,598 & &, $000^{\mathrm{a}}$ \\
\hline Residual & 27,320 & 94 &, 451 & & \\
\hline Total & 55,310 & 99 & & \\
\hline
\end{tabular}

a. Predictors: (Constant), sikap, motivasi, persepsi, emosi, pelatihan

b. Dependent Variable: sistem keuangan desa

Berdasarkan hasil pada tabel 2, didapat tingkat signifikan Uji Kelayakan Model $=0,000<0.05$ (level of signifikan), yang menunjukkan pengaruh variabel akuntansi keperilakuan model layak terhadap sistem keuangan desa dan dapat digunakan untuk penelitian lebih lanjut.

\section{Uji Koefisien Determinasi $\left(\mathbf{R}^{2}\right)$}

Koefisien determinasi $\left(\mathrm{R}^{2}\right)$ pada intinya mengukur kemampuan model dalam menerangkan variabel terikat. Nilai koefisien determinasi adalah diantara nol dan satu. Hasil dari uji koefisien determinasi yang nampak pada tabel 3 sebagai berikut :

Tabel 3 
Hasil Uji Koefisien Determinasi

\begin{tabular}{|l|l|l|l|l|}
\hline Model & $\mathrm{R}$ & $\mathrm{R}$ Square & Adjusted R Square & $\begin{array}{l}\text { Std.Error of the } \\
\text { Estimate }\end{array}$ \\
\hline 1 &, $711^{\mathrm{a}}$ &, 680 &, 701 &, 699 \\
\hline
\end{tabular}

a. Predictors: (Constant), sikap, motivasi, persepsi, emosi, pelatihan

b. Dependent Variable: sistem keuangan desa

Berdasarkan hasil pada Tabel 3, didapat $\mathrm{R}$ square $\left(\mathrm{R}^{2}\right)$ sebesar 0,680 atau $68 \%$ yang menunjukkan kontribusi dari variabel akuntansi keperilakuan terhadap sistem keuangan desa. Sedangkan sisanya $32 \%$ dikontribusi oleh faktor lain diluar model penelitian. Koefisien korelasi berganda ditunjukkan dengan (R) sebesar 0,711 atau $71,1 \%$ yang mengindikasikan bahwa adanya hubungan yang baik antara variabel dependen terhadap variabel independen.

\section{PEMBAHASAN}

\section{Pengaruh Akuntansi keperilakuan berupa sikap terhadap Sistem Keuangan Desa}

Pada dasarnya sikap seseorang itu sangat berpengaruh terhadap tindakan yang akan diambil, sikap diartikan sebagai pendapat yang dapat diaplikasikan dalam sikap yang pada akhirnya akan mempengaruhi tindakan yang diambil dalam hal ini tindakan dalam proses pembuatan laporan keuangan.

\section{Pengaruh Akuntansi keperilakuan} berupa motivasi terhadap Sistem

\section{Keuangan Desa}

Dalam tabel ditemukan bahwa motivasi memiliki pengaruh terhadap sistem keuangan desa tapi pengaruhnya tidak signifikan, dikarenakan setiap operator dalam menjalankan fungsinya memiliki pengaruh yang berbeda - beda sehingga tidak dapat digeneralisasi untuk seluruh operator siskeudes.

\section{Pengaruh Akuntansi keperilakuan berupa persepsi terhadap Sistem} Keuangan Desa

Persepsi memiliki peran sendiri terhadap sistem keuangan desa dikarenakan persepsi yang dibangun juga akan mempengaruhi pola pikir dari operator tersebut. Namun persepsi tidak memiliki pengaruh yang cukup signifikan dikarenakan operator dalam menjalankan fungsinya memiliki pemahaman yang berbeda-beda.

\section{Pengaruh Akuntansi keperilakuan} berupa emosi terhadap Sistem Keuangan Desa

Sama halnya dengan persepsi, emosi juga memiliki peran sendiri dalam menjalankan fungsinya karena itu emosi juga tidak memiliki peran yang cukup signifikan dalam penelitian ini. 
Pengaruh Akuntansi keperilakuan berupa pelatihan terhadap Sistem Keuangan Desa

Dalam sistem keuangan desa, pelatihan memilki peran yang cukup signifikan dikarenakan pelatihan itu sendiri mampu meningkatkan kapasitas dari operator yang menjalankan sistem keuangan desa.

\section{PENUTUP}

Kesimpulan dari penelitian ini adalah sebagai berikut (1) sikap berpengaruh positif signifikan terhadap implementasi sistem keuangan desa. Artinya semakin baik sikap dalam bekerja maka semakin baik dalam mengimplementasikan sistem keuangan desa (2) motivasi tidak berpengaruh terhadap implementasi sistem keuangan desa. Artinya hasil penelitian mengenai pengaruh motivasi operator Siskeudes tidak dapat digeneralisasi untuk seluruh operator sistem keuangan desa dalam mengimplementasikan sistem keuangan desa (3) persepsi berpengaruh terhadap implementasi sistem keuangan desa namun pengaruhnya kecil. artinya hasil penelitian mengenai pengaruh persepsi operator Siskeudes tidak dapat digeneralisasi untuk seluruh operator sistem keuangan desa dalam mengimplementasikan sistem keuangan desa (4) emosi berpengaruh terhadap implementasi sistem keuangan desa namun pengaruhnya kecil. artinya hasil penelitian mengenai pengaruh emosi operator Siskeudes tidak dapat digeneralisasi untuk seluruh operator sistem keuangan desa dalam mengimplementasikan Siskeudes, pelatihan berpengaruh positif signifikan terhadap implementasi sistem keuangan desa. Artinya semakin sering operator Siskeudes mengikuti pelatihan maka semakin memahami dalam impelementasi sistem keuangan desa. Implikasi hasil penelitian ini bahwa keberhasilan sistem keuangan desa tidak terlepas dari perilaku operator tersebut. Adapun indikator yang mempunyai kontribusi dan signifikan dalam mempengaruhi implementasi Siskeudes yaitu dengan indikator sikap dan pelatihan. Akan tetapi indikator motivasi, persepsi dan emosi tidak dapat digeneralisasi untuk seluruh operator Siskeudes.

Adapun saran yang dapat peneliti sampaikan yaitu untuk penelitian selanjutnya dapat mempeluas objek penelitian dengan membandingkan pada wilayah yang berbeda baik itu di kabupaten/ kota maupun berbeda provinsi serta dapat menambah variabel lain yang 
tidak diteliti dalam penelitian ini seperti indikator pembelajaran dan lain-lain.

\section{DAFTAR PUSTAKA}

Akay, E. M., Poputra, A. T., \& Kalalo, M. Y. B. (2016). Analisis Aspek Keperilakuan Terhadap Penerapan Sistem Akuntansi Persediaan Pada PT. Surya Wenang Indah Manado. Jurnal Riset Ekonomi, Manajemen, Bisnis Dan Akuntansi, 4(1), 688697

Arfan, Ikhsan dan Muhammad ishak, 2005, Akuntansi Keperilakuan, Salemba Empat, Jakarta

Lubis, A. I. (2017). Akuntansi Keperilakuan (edisi 2). Salemba Empat.

Luthans, F. (2005). Organizational Behavior, New York: McGrawHill, Inc

Mangkuprawira, S. (2011). Manajemen Sumber Daya Manusia Strategik (edisi kedu). Ghalia Indonesia.

Mardiasmo.2011.Akuntansi Sektor Publik. Yogyakarta. Salemba Empat.

Medan. Pascasarjana Universitas Sumatera Utara.

Rombe, A., Poputra, A. T., \& Kalalo, M. Y. B. (2016). Analisis Sistem Kas Berbasis Akuntansi Keperilakuan Dalam Pelaporan Arus Kas Pada
PT. Bank Sulutgo. Jurnal Berkala Ilmiah Efisiensi, 16(01), 459-469.

Rosnidah, I., Sulistyowati, W. A., \& Yulianto, A. (2017). The Effects of Ethical Orientation and Moral Intensity on the Ethical Decision of an Auditor. Devotio: Journal of Business and Economic Studies, 11(1), 55-70.

Santa, I. G. N. H., \& Damayanti, I. G. A. E. (2018). Pengaruh Pelatihan, Dukungan Manajemen Puncak, Kejelasan Tujuan, Kemampuan Teknik Personal Pada Penggunaan Sistem Informasi Akuntansi. EJurnal Akuntansi Universitas Udayana, 22(1), 138-157.

Siegel, \& Marconi. (1989). Behavioral Accounting. Shouth Western Publising Co.

Sugiyono. 2012. Metode Penelitian Kombinasi. Bandung : Alfabeta.

Uma Sekaran, 2006, Research Methods For Business, Edisi 4, Buku 1, Jakarta: Salemba Empat.

Wibowo. (2014). Manajemen Kinerja (keempat). Rajawali Pers 